\title{
Placental extract suppresses the formation of fibrotic deposits by tumor necrosis factor alpha and transforming growth factor beta-induced epithelial-mesenchymal transition in ARPE-19 cells
}

\author{
Kyoko Igarashi, Koji Sugimoto and Eiichi Hirano* (1)
}

\begin{abstract}
Objective: Epithelial-mesenchymal transition (EMT) is involved in the development of proliferative vitreoretinopathy (PVR) and subsequent fibrosis. Previously, we demonstrated that placental extract ameliorates fibrosis in a mouse model of non-alcoholic steatohepatitis. In this study, we evaluated whether placental extract influences EMT and fibrosis through cytokine-induced EMT in the retinal pigment epithelial cells, in vitro.

Results: Placental extract did not inhibit EMT, but it suppressed excessive mesenchymal reactions and the subsequent fibrosis. These results suggest that placental extract effectively ameliorates EMT-associated fibrosis in PVR. This beneficial effect could be partially attributed to the suppression of excessive mesenchymal reactions.
\end{abstract}

Keywords: Placental extract, Bioactivity, Epithelial-mesenchymal transition, Fibrosis, ARPE-19, Proliferative vitreoretinopathy

\section{Introduction}

Proliferative vitreoretinopathy (PVR) is a complication with very poor visual outcomes, following the surgery for retinal detachment and ocular injury [1,2]. PVR is characterized by the formation of a proliferative membrane in which cells migrate, and then proliferate under the retina or on the retina; this is triggered by ocular injury or retinal tear [3-5]. The cells involved in proliferation are the retinal pigment epithelial cells (RPE), astrocytes, fibroblasts, myofibroblasts, and macrophages. The main cellular components of PVR membranes are RPE cells. The RPE cells are non-proliferating, monolayered, nonmotile, and polar, under normal conditions. However,

\footnotetext{
*Correspondence: ehirano@placenta-jbp.co.jp

Research Institute, Japan Bio Products Co., Ltd., 1-1 Kurume Research Center bldg. 2F, Hyakunenkoen, Kurume 839-0864, Japan
}

RPE cells proliferate and dedifferentiate to form a multilayer structure under pathological conditions, such as retinal detachment [6]. Epithelial-mesenchymal transition (EMT) is characterized by a loss of epithelial cell phenotype and a gain of mesenchymal phenotype, including the enhancement of cell motility and migration. EMT is functionally classified into three subtypes: type I, II, and III. Type I EMT is related to implantation and embryogenesis, type II is associated with inflammation and fibrosis, and type III is closely related to tumor metastasis. Most studies on EMT involve cancers [7]. The major pathogenesis of PVR could be the conversion of RPE cells into mesenchymal cells through EMT [8]. During chronic inflammation, EMT is continuously induced by cytokines, growth factors, and reactive oxygen species [9], and fibrosis is induced by excessive extracellular 
matrix deposition, indicating that fibrogenesis is caused by EMT [10].

Placental extract has many biological activities, such as stimulation of liver regeneration [11], anti-oxidation [12], anti-apoptosis [9], and the suppression of cardiac hypertrophy [13]. Clinically, placental extract is an injectable made from the components derived from the human placenta; it improves liver function in chronic hepatitis. Oral porcine placental extract ameliorates menopausal symptoms. Placental extract ameliorates fibrosis in a methionine- and choline-deficient diet-induced mouse model of non-alcoholic steatohepatitis [13, 14]. Therefore, we hypothesized that placental extract could attenuate fibrosis caused by EMT. We evaluated whether placental extract influences EMT and fibrosis by inducing EMT in retinal pigment epithelial cells in vitro.

\section{Main text}

\section{Materials and methods}

\section{Placental extracts and cytokines}

Porcine or equine placental extracts were obtained from Japan Bio Products Co., Ltd. (Tokyo, Japan). Human recombinant tumor necrosis factor $\alpha$ (TNF- $\alpha)$ and transforming growth factor $\beta 2$ (TGF- $\beta 2$ ) were obtained from Peprotech.

\section{Cell culture}

Human ARPE-19 cells (from ATCC cell line) were cultured in Ham's F12 media mixed with DMEM (1:1) and supplemented with $10 \%$ fetal bovine serum, $2 \mathrm{mM}$ L-glutamine, $100 \mathrm{units} / \mathrm{mL}$ penicillin, and $100 \mu \mathrm{g} / \mathrm{mL}$ streptomycin, at $37^{\circ} \mathrm{C}$ in humidified air containing $5 \% \mathrm{CO}_{2}$.

\section{Cell viability assay}

ARPE-19 cells were placed on 96-well plates at a density of $1.0 \times 10^{4}$ cells/well. After $24 \mathrm{~h}$, cells were washed with culture media once, and then treated with a serial dose of equine and porcine placental extract for $96 \mathrm{~h}$. The cytotoxicity of equine and porcine placental extract on ARPE19 cells was evaluated using the sulforhodamine B (SRB) assay. The cells were fixed with $50 \%$ Trichloroacetic acid for $60 \mathrm{~min}$ in fridge, washed with tap water, air-dried at room temperature for $60 \mathrm{~min}$, and stained with $0.4 \%$ SRB solution (Sigma) at room temperature for $25 \mathrm{~min}$. After neutralization with $10 \mathrm{mM}$ Tris base solution, and then were measured the absorbance at $565 \mathrm{~nm}$ in a microplate reader. This assay was independently repeated on three times.

\section{EMT-associated fibrotic deposits (EAFD) assay}

EMT-associated fibrotic deposits (EAFD) assay was performed as described previously [15]. ARPE-19 cells were placed on 12-well plates at a density of $5.0 \times 10^{4}$ cells/ well. After $72 \mathrm{~h}$, cells were washed with culture media without serum twice, and then cultured for $96 \mathrm{~h}$ without serum in the presence of TNF- $\alpha(10 \mathrm{ng} / \mathrm{mL})$, TGF- $\beta 2$ ( $5 \mathrm{ng} / \mathrm{mL}$ ), or a serial dose of placental extract. The cells were fixed with methanol for $5 \mathrm{~min}$, air-dried at room temperature for $5 \mathrm{~min}$, and stained with Giemsa solution (Merck) for $15 \mathrm{~min}$. The number of EAFDs was counted using a light microscope and normalized using Photoshop. This assay was independently repeated on three times.

\section{Quantitative real-time $P C R$ ( $q P C R$ )}

Culture and drug treatment of ARPE-19 cells were as same as above "EMT-associated Fibrotic Deposits (EAFD) Assay" section. Total RNA was extracted from ARPE-19 cells using TRI Reagent (TR118, MRC, $\mathrm{OH}$, USA) and cDNA was synthesized using the PrimeScript RT reagent Kit with gDNA Eraser (Takara Bio Inc., Japan). qPCR was performed as previously described [16]. The primer sequences are listed in Additional file 1: Table S1. The data were analyzed using the $2^{-\Delta \Delta} C_{\mathrm{T}}$ method and normalized to the levels of human TATA-box binding protein (Tbp) mRNA, which was used as an endogenous control. This assay was independently repeated on three times.

\section{Statistical analysis}

All values are expressed as mean $\pm \mathrm{SD}$ of at least two independent experiments. One-way ANOVA with posthoc Scheffe's test was used to determine the significance of differences. Statistical significance was set at $\mathrm{p}<0.05$.

\section{Results}

Influence of placental extract on the ARPE-19 cell viability The cell viability following $96 \mathrm{~h}$ of treatment with $\mathrm{pPE}$ and ePE in ARPE-19 cells was determined using the SRB assay, and the results are shown in Fig. 1. Cell viability was $100.9 \% \pm 1.1 \%, 107.8 \% \pm 0.4 \%$, and $105.0 \% \pm 4.5 \%$ following treatment with $0.2,2.0$, and $4.0 \mathrm{mg} / \mathrm{mL}$ of pPE, respectively. In the case of ePE treatment, cell viability was $99.4 \% \pm 1.6 \%, 99.7 \% \pm 0.9 \%$, and $98.5 \% \pm 2.5 \%$ following treatment with $0.2,2.0$, and $4.0 \mathrm{mg} / \mathrm{mL}$ of ePE, respectively. Therefore, there was no significant difference in the cell viability in both pPE and ePE treatments, compared to that in the control.

\section{Inhibitory effect of placental extract on the formation of EAFD in TNF- $\alpha$ and TGF- $\beta 2$ treated ARPE- 19 cells}

It has been reported that the combinative effect of tumor necrosis factor $\alpha$ (TNF- $\alpha$ ) with transforming growth factor $\beta 2$ (TGF- $\beta 2$ ) induce EMT in ARPE-19 cells, resulting in the formation of cellular aggregates, which are EMTassociated fibrotic deposits (EAFD) $[15,20]$. TNF- $\alpha$ - and 


\section{a}

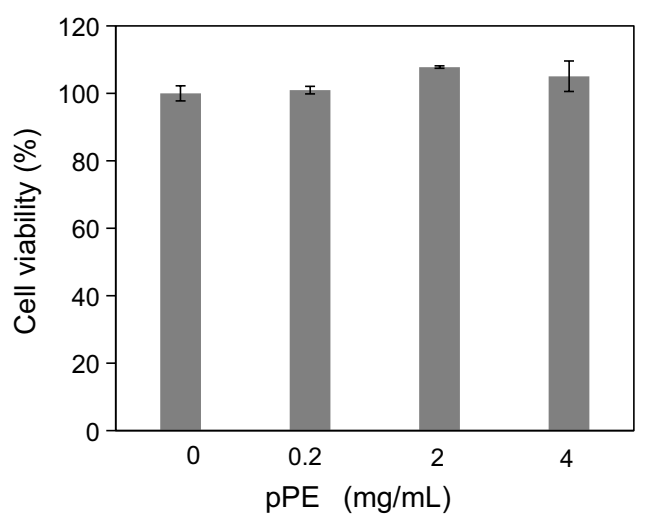

b

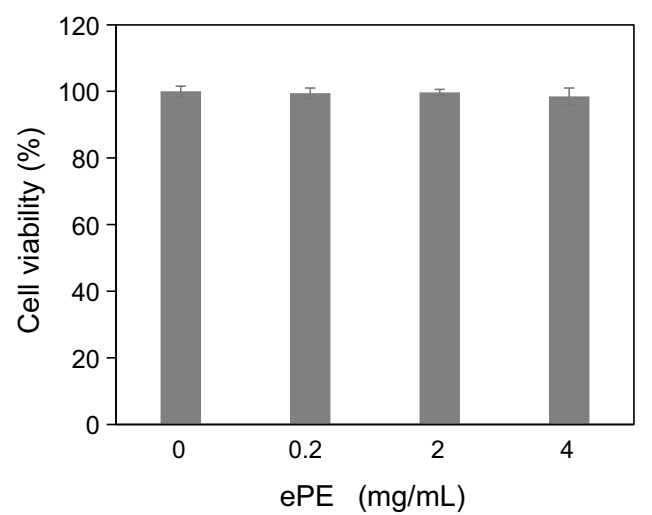

Fig. 1 Effect of placental extract on the viability of ARPE-19 cells. Cell viability was measured using the SRB assay. ARPE-19 cells were incubated with varying concentrations $(0.4,2.0$, and $4.0 \mathrm{mg} / \mathrm{mL})$ of placental extract, for $96 \mathrm{~h}$. a pPE and $\mathbf{b}$ ePE treatments. Data are expressed as mean \pm SD of three independent experiments performed in triplicate

TGF- $\beta 2$ induced EMT in ARPE-19 cells is an initiating event in many fibrotic processes that occur during the pathogenesis of PVR [8]. We studied the effects of placental extract on the formation of EAFD in TNF- $\alpha$-and TGF- $\beta 2$ treated ARPE-19 cells using Giemsa staining of EAFD. Treatment with low dose of pPE $(0.4 \mathrm{mg} /$ $\mathrm{mL})$ or ePE $(0.4 \mathrm{mg} / \mathrm{mL})$ did not influence the formation of EAFD in TNF- $\alpha$ and TGF- $\beta 2$ treated ARPE-19 cells (Fig. 2a). However, high dose (at 2 and $4 \mathrm{mg} / \mathrm{mL}$ ) treatment remarkably inhibited the formation of EAFD (Fig. 2a). The area of EAFDs significantly decreased in the placental extract-treated group, compared to that in the control ( $2 \mathrm{mg} / \mathrm{mL}$ pPE; $23 \pm 6.4$ vs. $8.3 \pm 1.5, \mathrm{p}<0.01$; $4 \mathrm{mg} / \mathrm{mL} \mathrm{pPE} ; 23 \pm 6.4$ vs. $6.0 \pm 1.8, \mathrm{p}<0.01 ; 2 \mathrm{mg} / \mathrm{mL}$ ePE; $23 \pm 6.4$ vs. $6.0 \pm 1.4, \mathrm{p}<0.01 ; 4 \mathrm{mg} / \mathrm{mL}$ ePE; $23 \pm 6.4$ vs. $4.7 \pm 1.3, \mathrm{p}<0.01$ ) (Fig. $2 \mathrm{~b}$ ).

\section{Effect of equine placental extract on the expression EMT marker and development of PVR -related genes in TNF- $a$ and TGF- $\beta 2$ treated ARPE- 19 cells}

To evaluate the effects of $\mathrm{ePE}$ on the induction of the EMT by TNF- $\alpha$ and TGF- $\beta 2$ of ARPE- 19 cells, we performed qPCR to evaluate the gene expression of E-cadherin, ZO-1, and Krt18 (a well-known epithelial markers), and that of fibronectin, $N$-cadherin, and vimentin (representative mesenchymal markers). TNF- $\alpha$ and TGF- 32 significantly suppressed the expression of the epithelial marker genes (E-cadherin and Krt18, p $<0.01$; $Z O-1, \mathrm{p}<0.05)$, compared to that in the none group (neither TNF- $\alpha$ nor TGF- $\beta 2$-treated group). ePE treatment inhibited the expression of E-cadherin, ZO-1, and Krt18 in TNF- $\alpha$ and TGF- $\beta 2$-treated ARPE- 19 cells, compared to that in the control group (TNF- $\alpha$ and TGF- $\beta 2$-treated group) (Fig. 3a). Among the mesenchymal marker genes, the expression of fibronectin, $N$-cadherin, and vimentin were significantly increased $(\mathrm{p}<0.01)$ by TNF- $\alpha$ and TGF- $\beta 2$ of in ARPE-19 cells, compared to that in the none group. ePE significantly blocked the increase in the expression of these epithelial marker genes, compared to that in the control group ( $N$-cadherin and vimentin, $\mathrm{p}<0.01$; fibronectin, $\mathrm{p}<0.05$ ) (Fig. 3b). Since various proteases and extracellular matrix (ECM) are known to be involved in the development of PVR [20], we evaluated the expression level of Colla1 and $M m p-2$ genes in ARPE-19 cells. TNF- $\alpha$ and TGF- $\beta 2$ significantly increased the expression of Colla1 and Mmp-2 (Colla1 and $M m p-2, \mathrm{p}<0.01)$, compared to that in the none group; while, ePE significantly blocked the upregulation of these genes, compared to that in the control group (Colla1 and Mmp-2, p <0.01) (Fig. 3c).

\section{Discussion}

EMT-inhibiting agents are derived from naturally occurring products such as resveratrol, quercetin, curcumin, and epigallocatechin gallate [17-19]. However, they have been mentioned little of the EMT-associated Fibrotic Deposits, which is EMT-associated fibrosis by TNF- $\alpha$ and TGF- $\beta 2$-treatment. There are synthetic chemicals that inhibit both EMT and EMT-associated fibrotic deposits in vitro; these include the AMPK activator, 5-aminoimidazole-4-carboxamide ribonucleotide (AICAR); an antiallergy dug, $\mathrm{N}$-[3', $4^{\prime}$-dimethoxycinnamoyl $]$ anthranilic acid (Tranilast), which is a specific inhibitor of TGF- $\beta$ receptor I (SB43152); and a hyaluronic acid synthase inhibitor, 4-methylumbelliferone (4-MU) $[15,20,21]$. These chemicals inhibit the formation of 
a

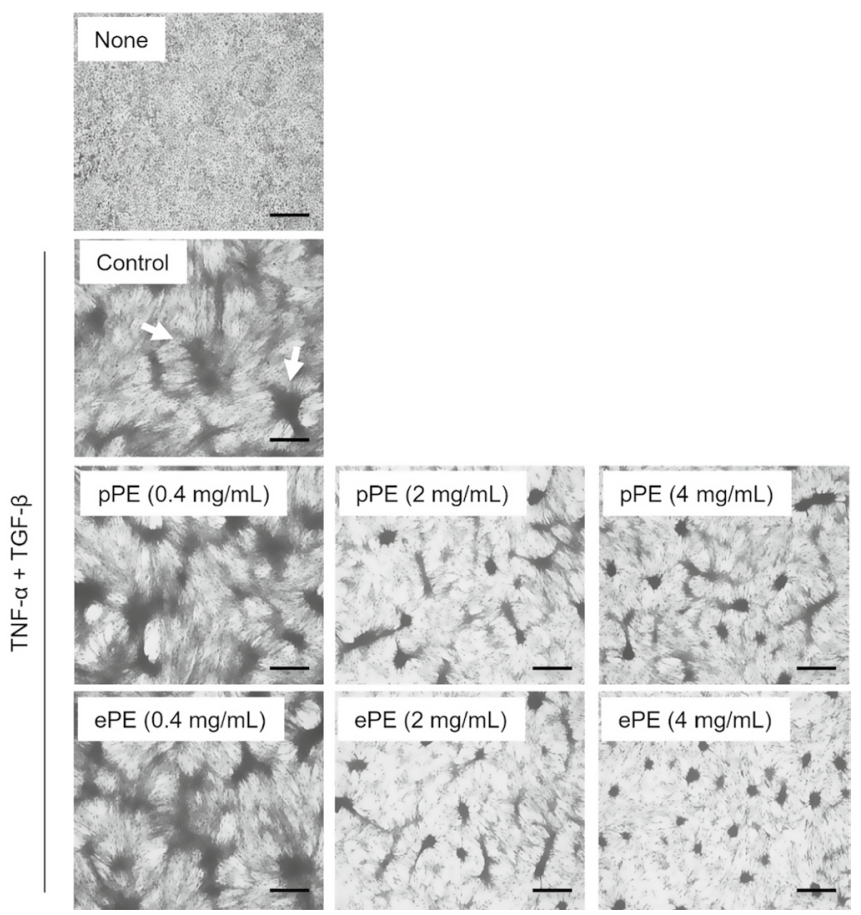

b

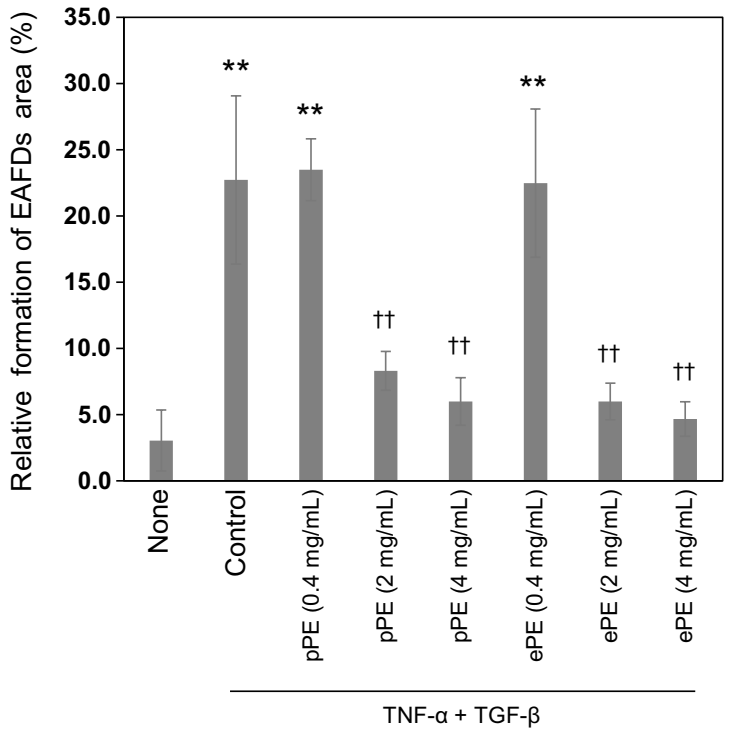

Fig. 2 Placental extract inhibited the formation of EAFDs by TNF- $\alpha$ and TGF- $\beta 2$ in ARPE-19 cells. a The formation of EAFDs was detected using Giemsa staining and the cells were counted through microscopic observation. Data are expressed as mean \pm SD of at least four different fields, in each of three independent experiments. Arrows indicate EMT-induced EAFDs. Scale bars, $500 \mu \mathrm{m}$. b Quantification of the EAFD areas. Representative data are shown. ${ }^{* *} p<0.01$ vs. None. ${ }^{\dagger \dagger} p<0.01$ vs. Control

EMT-associated fibrotic deposits; while, ePE prevented the growth of EMT-associated fibrotic deposits, suggesting that ePE differs in its mechanism of action from these chemicals.

ePE did not inhibit EMT; however, it prevented excessive mesenchymal reactions and the subsequent fibrosis. However, the suppression of excessive mesenchymal reactions in EMT needs further elucidation. EMT is closely related to tumor metastasis; and therefore, most studies on EMT involve cancers; the therapeutic strategies are mostly focused on the prevention of EMT. Excessive mesenchymal reactions play a key role in the progression of neurofibromas [22]. ePE has a novel mode of action, which leads to the development of new therapeutic strategies, such as combination therapy with ePE and EMT inhibitors. ePE is a novel candidate for the treatment of EMT-associated fibrosis. In addition, the suppressive effect of the excessive mesenchymal reaction could be beneficial in cancer therapy, in particular, in inhibiting the activation of mesenchymal-like cells, such as the MDA-MB-157 (human breast cancer line).
In conclusion, we found that ePE inhibited EMTassociated fibrotic deposits in TNF- $\alpha$-and TGF- $\beta 2$ treated ARPE-19 cells. ePE partially suppressed the expression of mesenchymal marker genes (fibronectin, $N$-cadherin, and vimentin) and ECM-related genes (Colla1 and Mmp-2) in TNF- $\alpha$-and TGF- $\beta 2$-treated ARPE-19 cells. Therefore, ePE could be useful for the prevention of excessive mesenchymal reactions and subsequent fibrosis.

\section{Limitations}

This study was limited to in vitro results, and thus there is a need for further in vivo investigation. Further studies are needed to clarify active ingredients in placental extract for preventing excessive mesenchymal reactions and the subsequent fibrosis, and then elucidate the mode of action of them. 
a

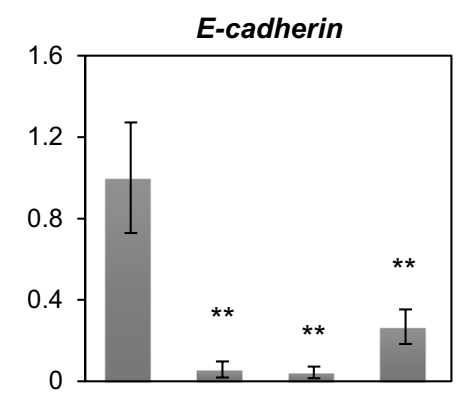

$\mathrm{ZO}-1$
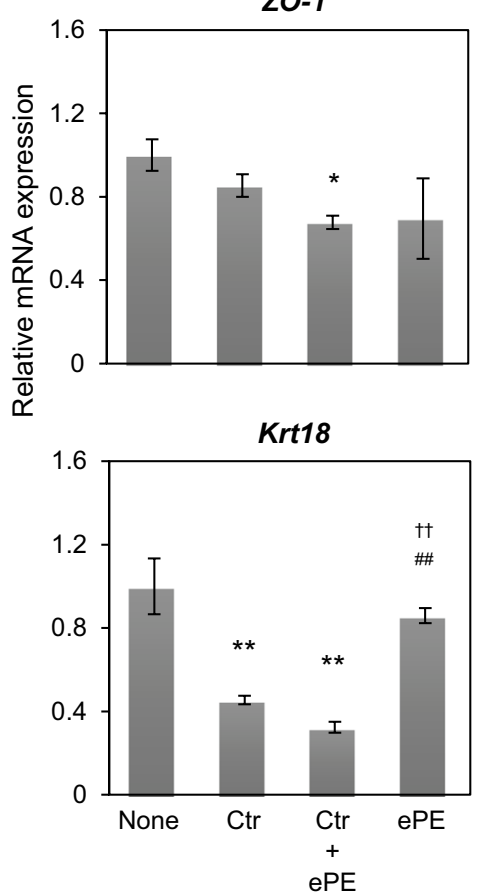

b
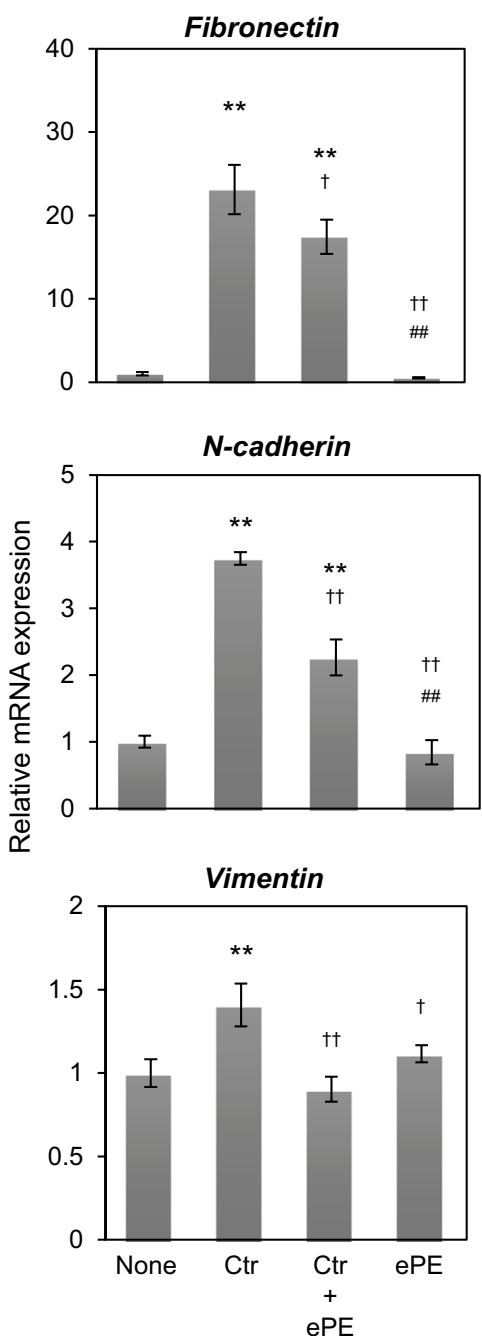

C

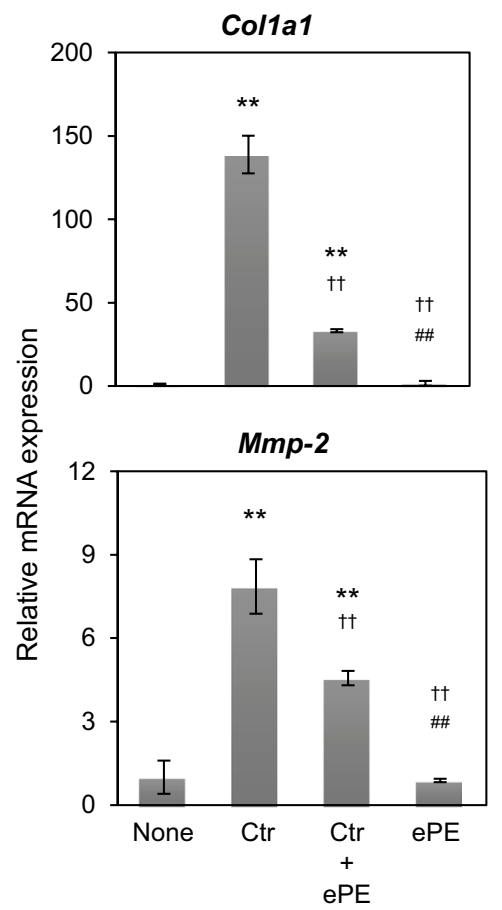

Fig. 3 Effect of equine placental extract on the expression of EMT marker and development of PVR -related genes in TNF- $\alpha$ and TGF- $\beta 2$ treated ARPE-19 cells. The expression levels of the epithelial and mesenchymal phenotype marker genes were determined using qPCR analysis. Cells were treated with TNF- $a$ and TGF- $\beta 2$ in the presence or absence (control group) of $4 \mathrm{mg} / \mathrm{mL}$ ePE..a epithelial marker genes (E-cadherin, ZO-1, Krt18), b mesenchymal genes (fibronectin, $\mathrm{N}$-cadherin, and vimentin), c development of PVR-related genes (Colla1 and Mmp-2). The results are presented as mean $\pm S D(n=3)$, for three independent experiments. ${ }^{*} p<0.05,{ }^{* *} p<0.01$ versus corresponding no treatment (none group), ${ }^{+} p<0.05,{ }^{+\dagger} p<0.01$ versus corresponding treatment with TNF- $a$ and TGF- $\beta 2$ in the absence of ePE. ${ }^{\#} p<0.01$, versus corresponding treatment with TNF- $a$ and TGF- $\beta 2$ in the presence of ePE

\section{Abbreviations}

Col1A1: Collagen type I alpha 1 chainCtr: control; ECM: Extracellular matrix; EMT: Epithelial-mesenchymal transition; ePE: Equine placental extract; Krt18: Keratin 18; Mmp-2: Matrix metalloproteinase-2; PPE: Porcine placental extract; PVR: Proliferative vitreoretinopathy; Tbp: TATA-binding protein; ZO-1: Zona occludens- 1 .

\section{Supplementary Information}

The online version contains supplementary material available at https://doi. org/10.1186/s13104-021-05824-0.

Additional file 1: Table S1. Primers used for quantitative real-time PCR.

\section{Acknowledgements}

We thank Professor Koji Tamada in the Department of Immunology, Graduate School of Medicine, Yamaguchi University, Japan, for critical discussions. We also appreciate Editage (www.editage.jp) for English language editing. This work was supported by Japan Bio Products Co., Ltd.

\section{Authors' contributions}

$\mathrm{Kl}$ : performed the experiments; contributed reagents, materials, analysis tool or data. KS: analyzed and interpreted the data. EH; conceived and designed the experiments, wrote the paper. All authors read and approved the final manuscript.

\section{Funding}

The author(s) received no financial support for the research, authorship, and/ or publication of this article. 


\section{Availability of data and materials}

The datasets used during this study are available from the corresponding author upon reasonable request.

\section{Declarations}

Ethics approval and consent to participate

Not applicable.

\section{Consent to publish}

Not applicable.

\section{Competing interests}

All authors are employees of Japan Bio Products Co., Ltd.

Received: 6 July 2021 Accepted: 26 October 2021

Published online: 02 November 2021

\section{References}

1. Leaver PK. Proliferative vitreoretinopathy. Br J Ophthalmol. 1995:79:871-2.

2. Abrams GW, Azen SP, McCuen BW, Flynn HW, Lai MY, Ryan SJ. Vitrectomy with silicone oil or long-acting gas in eyes with severe proliferative vitreoretinopathy: results of additional and long-term follow-up. Silicone Study report 11. Arch Ophthalmol. 1997;115:335-44.

3. Cardillo JA, Stout JT, LaBree L, Azen SP, Omphroy L, Cui JZ, Kimura H, Hinton DR, Ryan SJ. Post-traumatic proliferative vitreoretinopathy. The epidemiologic profile, onset, risk factors, and visual outcome. Ophthalmology. 1997; 104:1166-73.

4. Tseng W, Cortez RT, Ramirez G, Stinnett S, Jaffe GJ. Prevalence and risk factors for proliferative vitreoretinopathy in eyes with rhegmatogenous retinal detachment but no previous vitreoretinal surgery. Am J Ophthalmol. 2004;137:1105-15.

5. Pennock S, Haddock LJ, Eliott D, Mukai S, Kazlauskas A. Is neutralizing vitreal growth factors a viable strategy to prevent proliferative vitreoretinopathy? Prog Retin Eye Res. 2014;40:16-34.

6. Hiscott P, Sheridan C, Magee RM, Grierson I. Matrix and the retinal pigment epithelium in proliferative retinal disease. Prog Retin Eye Res. 1999:18:167-90

7. Kalluri R, Weinberg RA. The basics of epithelial-mesenchymal transition. J Clin Invest. 2009;119:1420-8.

8. Toshi GM, Marigliani D, Romeo N, Toti P. Disease pathways in proliferative vitreoretinopathy: an ongoing challenge. J Cell Physiol. 2014;229:1577-83.

9. Bak DH, Na J, Choi MJ, Lee BC, Oh CT, Kim JY, Han HJ, Kim MJ, Kim TH, Kim BJ. Anti-apoptotic effects of human placental hydrolysate against hepatocyte toxicity in vivo and in vitro. Int J Mol Med. 2018:42:2569-83.

10. Matsuzaki S, Darcha C. Involvement of the Wnt/beta-catenin signaling pathway in the cellular and molecular mechanisms of fibrosis in endometriosis. PLOS ONE. 2013:8:e76808.
11. Liu K, Kato Y, Kaku T, Sugiyama Y. Human placental extract stimulates liver regeneration in rats. Biol Pharm Bull. 1998;21:44-9.

12. Bak DH, Na J, Im SI, Oh CT, Kim JY, Park SK, Han HJ, Seok J, Choi SY, Ko EJ, Mun SK, Ahn SW, Kim BJ. Antioxidant effect of human placenta hydrolysate against oxidative stress on muscle atrophy. J Cell Physiol. 2019;234:1643-58.

13. Yamauchi A, Kamiyoshi A, Koyama T, linuma N, Yamaguchi S, Miyazaki H, Hirano E, Kaku T, Shindo T. Placental extract ameliorates non-alcoholic steatohepatitis (NASH) by exerting protective effects on endothelial cells. Heliyon. 2017;3:e00416.

14. Yamauchi A, Kamiyoshi A, Sakurai T, Miyazaki H, Hirano E, Lim HS, Kaku T, Shindo T. Placental extract suppresses cardiac hypertrophy and fibrosis in an angiotensin II-induced cachexia model in mice. Heliyon. 2019;5:e02655.

15. Takahashi E, Nagano O, Ishimoto T, Yae T, Suzuki Y, Shinoda T, Nakamura S, Niwa S, Ikeda S, Koga H, Tanihara H, Saya H. Tumor necrosis factor-alpha regulates transforming growth factor-beta-dependent epithelial-mesenchymal transition by promoting hyaluronan-CD44-moesin interaction. J Biol Chem. 2010;285:4060-73.

16. Yamauchi A, Tone T, Sugimoto K, Lim HS, Kaku T, Tohda C, Shindo T, Tamada K, Mizukami Y, Hirano E. Porcine placental extract facilitates memory and learning in aged mice. Food Sci Nutr. 2019;7:2995-3005.

17. Chen CL, Chen YH, Tai MC, Liang CM, Lu DW, Chen JT. Resveratrol inhibits transforming growth factor- $\beta 2$-induced epithelial-to-mesenchymal transition in human retinal pigment epithelial cells by suppressing the Smad pathway. Drug Des Devel Ther. 2017;11:163-73.

18. Cai W, Yu D, Fan J, Liang X, Jin H, Liu C, Zhu M, Shen T, Zhang R, Hu W, Wei Q, Yu J. Quercetin inhibits transforming growth factor $\beta 1$-induced epithelial-mesenchymal transition in human retinal pigment epithelial cells via the Smad pathway. Drug Des Devel Ther. 2018;6:4149-61.

19. Shanmuganathan S, Sumantran VN, Angayarkanni N. Epigallocatechin gallate \& curcumin prevent transforming growth factor beta 1-induced epithelial to mesenchymal transition in ARPE-19 cells. Indian J Med Res. 2017;146:85-96.

20. Matoba R, Morizane Y, Shiode Y, Hirano M, Doi S, Toshima S, Araki R, Hosogi M, Yonezawa T, Shiraga F. Suppressive effect of AMP-activated protein kinase on the epithelial-mesenchymal transition in retinal pig ment epithelial cells. PLoS ONE. 2017;12:e0181481.

21. Harigai R, Sakai S, Nobusue H, Hirose C, Sampetrean O, Minami N, Hata Y, Kasama T, Hirose T, Takenouchi T, Kosaki K, Kishi K, Saya H, Arima Y. Tranilast inhibits the expression of genes related to epithelial-mesenchymal transition and angiogenesis in neurofibromin-deficient cells. Sci Rep. 2018;8:6069.

22. Arima Y, Hayashi H, Kamata K, Goto TM, Sasaki M, Kuramochi A, Saya $H$. Decreased expression of neurofibromin contributes to epithelialmesenchymal transition in neurofibromatosis type 1. Exp Dermatol. 2010;19:e136-41.

\section{Publisher's Note}

Springer Nature remains neutral with regard to jurisdictional claims in published maps and institutional affiliations.
Ready to submit your research? Choose BMC and benefit from:

- fast, convenient online submission

- thorough peer review by experienced researchers in your field

- rapid publication on acceptance

- support for research data, including large and complex data types

- gold Open Access which fosters wider collaboration and increased citations

- maximum visibility for your research: over 100M website views per year

At BMC, research is always in progress.

Learn more biomedcentral.com/submissions 